\title{
Model Predict, Observe and Explain Pembelajaran Muatan IPS Kelas IV di SDN Pondok Bambu 06 Jakarta
}

\section{Predict, Observe and Explain Learning Model on Social Sciences Subject of Fourth Grade in SDN Pondok Bambu 06 Jakarta}

\author{
Ajat Sudrajat ${ }^{1}$, Dudung Amir Soleh ${ }^{2}$, Winda Dewi Lityasari ${ }^{3}$, Vina Iasha ${ }^{4}$ \\ Universitas Terbuka, Indonesia ${ }^{1}$; Universitas Negeri Jakarta, Indonesia ${ }^{2,3}$; \\ SD Negeri Pondok Bambu 06 Jakarta, Indonesia ${ }^{4}$
}

\begin{tabular}{l} 
ARTICLE INFO \\
\hline Article history: \\
DOI: \\
10.30595/pssh.v1i.73 \\
Submitted: \\
April 12, 2021 \\
Accepted: \\
June 10, 2021 \\
Published: \\
June 14, 2021 \\
\hline
\end{tabular}

Keywords:

model predict, observe and explain, social studies content, learning outcomes

\begin{abstract}
The background of the research is the fact that learning outcomes are still below the KKM on social studies content, namely $80 \%$. Researchers used Predict, Observe and Explain models in improving SD social studies learning outcomes. The research model design was classroom action research which was adapted from the model of Kemmis and Mc.Taggart. The tools used to collect data in this study were student and teacher observation data to see the application of the Predict, Observe and Explain models and evaluation sheets in measuring the improvement of learning outcomes. The research achievement can be seen from the application of the Predict, Observe and Explain model stages to students and teachers which exceed $90 \%$ and the percentage of learning outcomes exceeds $80 \%$. Discussion, learning outcomes in cycle I is $52 \%$, cycle II is $65 \%$ and cycle III is $100 \%$. Student observations in the first cycle were $60 \%$, the second cycle was 74 , the third cycle was 92 . Meanwhile, the teacher's observation in cycle I is 70 , cycle II is 78 , and cycle III is 96. It is concluded that the Predict, Observe and Explain model is very effective for teachers to increase their creative innovation abilities and can improve learning outcomes, especially in grade IV SD social studies content. In cycle I there are still weaknesses of students who have not adapted to the learning carried out by the teacher. The teacher still hasn't done all the steps from the Predict, Observe and Explain model so that it needs to be corrected in the second cycle. In the second cycle students were able to adapt to the learning model carried out by the teacher. The teacher has started to master the Predict, Observe and Explain model but has not reached the target so it needs improvement for the third cycle. from the third cycle student learning outcomes as well as student monitoring actions and teacher monitoring actions using the Predict, Observe, and Explain models are as expected. It can be said that the Predict, Observe, and Explain models are alternative models used in elementary schools.
\end{abstract}

This work is licensed under a Creative Commons Attribution 4.0 International License.

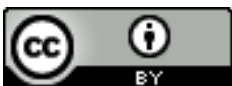

Corresponding Author:

Ajat Sudrajat

Universitas Terbuka Indonesia

Jalan Cabe Raya Pondok Cabe, Pd. Cabe Udik, Kec. Pamulang, Kota Tangerang Selatan, Banten 15437

Email: ajats@ecampus.ut.ac.id 
dan mempelajari lingkungan alam sekitar baik di rumah ataupun di sekolah. Muatan Ilmu Pengetahuan Sosial menekankan pada kemampuan siswa dalam memberikan solusi terhadap kondisi permasalahan sosial dan permasalahan lingkungan sekitar siswa dalam hal ini siswa diarahkan untuk dapat survive. muatan Ilmu Pengetahuan Sosial sangatlah penting untuk diajarkan kepada siswa di usia Sekolah Dasar. Oleh karena itu, guru harus dapat mendesain pembelajaran secara efektif, efisien, inovatif, dan bermakna bagi siswa dengan menyesuaikan struktur kognitif siswa usia Sekolah Dasar dan proses perkembangan siswa tersebut.

Guru sebagai tenaga pengajar diarahkan untuk dapat membimbing siswanya ke arah yang lebih baik agar hasil belajar siswa maksimal sesuai dengan ketuntasan standar minimal. Guru harus mempunyai model pembelajaran yang inovatif dalam mewujudkan pembelajaran yang menarik dan bermakna, serta dapat memberikan dampak langsung terhadap hasil belajar siswa. Berdasarkan kenyataan yang terjadi di Sekolah Dasar memperlihatkan bahwa proses pembelajaran di kelas dirasakan kurang berjalan secara optimal dan baik. Hal ini terlihat dari rendahnya hasil belajar yang dicapai siswa dalam muatan Ilmu Pengetahuan sosial yang tidak mencapai Kriteria Ketuntasan Minimal (KKM). Rendahnya hasil belajar dapat terihat dari hasil nilai siswa kelas IV, dari 25 siswa hanya 5 siswa atau 20\% yang mencapai target KKM dan 20 siswa atau $80 \%$ mendapatkan nilai kurang dari 80, sedangkan KKM Kelas IV Sekolah Dasar Negeri di SDN Pondok Bambu 06 Jakarta adalah 80.

Beberapa faktor yang mempengaruhi muatan Ilmu Pengetahuan Sosial di sekolah dasar kurang optimal dan baik, di antaranya: 1) muatan IPS bersifat hafalan dan teks bok; 2) muatan Ilmu Pengetahuan Sosial kurang menggunakan model pembelajaran yang tepat; 3) model yang digunakan masih ceramah, peserta didik merasa jenuh dan tidak termotivasi untuk belajar; 4) muatan Ilmu Pengetahuan Sosial.

Berdasarkan uraian permasalahan di atas, maka penyebab rendahnya hasil belajar muatan IPS di Sekolah Dasar Negeri di SDN Pondok Bambu 06 Jakarta adalah kurang tepatnya guru dalam menerapkan model pembelajaran sehingga muatan Ilmu Pengetahuan Sosial menjadi kurang efektif, efisien, bermakna, dan menyenangkan bagi siswa. Permasalahan tersebut memerlukan suatu model pembelajaran yang berbeda dan inovatif, yaitu model pembelajaran yang lebih interaktif, dapat memberikan siswa untuk lebih aktif didalam kelas. Salah satu model Predict, Observe, and Explain. Model Predict, Observe, and Explain adalah model yang menekankan pada keaktifan siswa dari menganalisis masalah, memecahkan masalah dan memberikan gagasan dan idenya dalam rangka memecahkan masalah tersebut.

Rumusan masalah: Apakah dengan menggunakan model Predict, Observe, and Explain dapat meningkatkan hasil belajar IPS kelas IV Sekolah Dasar Negeri di SDN Pondok Bambu 06 Jakarta?

Muatan IPS mempelajari kehidupan manusia secara baik, baik antar sesama manusia, baik antar lingkungan yang menjadi tempat tinggalnya. serta suatu ilmu yang membahas fenomena-fenomena sosial yang terjadi wilayah tempat tinggal kita. Hal ini sejalan dengan pendapat dari Daldjoeni (1985) bahwa pembelajaran IPS kajian masalah sosial ketika diajarkan kepada siswa guru harus dapat memahami dan mengerti karakteristik siswa sehingga siswa dapat dengan bersama memecahkan persoalan yang hadapinya dengan berbagai ilmu penunjang. sehingga diperlukan keterampilan guru IPS dalam rangka penyampian materi secara paripurna. Isjoni (2007) berpendapat bahwa diperlukan pengembangan dimensi pengetahuan, dimensi sikap, dan dimensi keterampilan dasar dalam rangka mengembangkan kemampuan personalnya secara nyata.

Pembelajaran IPS mensyaratkan bahwa guru diupayakan disamping mengajarkan konten materi sesuai dengan kurikulum yang berlaku juga mengajarkan sikap dan keterampilan yang baik sehingga betul-betul menjadi warga negara yang cinta terhadap diri dan lingkungannya. maka diperlukan guru yang pandai dan sigap dalam memanfaatkan lingkungan sekitar sebagai sumber belajar. Senada dengan Nursid (1986) berpendapat bahwa hakikat IPS adalah cara seseorang dengan menggunakan energinya untuk dapat memenuhi kebutuhan hidupnya, baik jiwa, budaya, kesejahteraan, sumber daya alam, dalam rangka pemenuhan dan mempertahankan kelangsungan hidup manusia secara hakiki.

Pembelajaran IPS mengupayakan siswa untuk menjadi warga negara yang adaptif dan responsif dengan kemajuan abad saat ini yang sudah memasuki abad 4.0 sehingga siswa mampu dapat berfikir kritis dan mampu memberikan solusi nyata bagi masalah yang terjadi di lingkungannya.

Model Predict, Observe, and Explain adalah siswa diberikan suatu permasalahan fenomena-fenomena tertentu dalam pembelajaran pada tahap ini siswa diajak untuk mencoba menduga sesuatu tentang pembelajaran, menganalisis fenomena masalah yang terjadi, kemudian siswa memberikan simpulan dalam bentuk argumentasi hasil diskusi dan pemikirannya lalu dipresentasikan dihadapan guru dan siswa lain. guru dan siswa lainnya memberikan tanggapan atau masukkan ide dan konsep terkait permasalahan tersebut. Suyono (2015) berpendapat terdapat tiga hal utama dalam Model Predict, Observe, and Explain yaitu: a) Predict, bahwa siswa melakukan dugaan atas fenomena atau peristiwa; b) Observe, bahwa siswa bisa melakukan dugaan melalui diskusi atau secara mandiri tentang fenomena tertentu; c) Explain, bahwa siswa memberikan penjelasan baik secara lisan dan tulisan terkait fenomena tertentu kemudian guru memberikan respon dan mencoba meluruskan tentang permasalahan tersebut sehingga siswa menjadi kritis dan dapat mengungkapkan ide-ide secara baik. 
Teerasong et all. (2007) bahwa, Model Predict, Observe, and Explain berpendapat bahwa siswa mempunyai kebebasan untuk mengembangkan dan mengungkapkan gagasan dan ide-ide secara konseptual melalui pengetahuan awal dan pengetahuan baru sehingga siswa dapat memperjelas konsepnya secara paripurna.

Model Predict, Observe, and Explain lebih dominan kepada siswa yang aktif untuk memecahkan suatu persoalan-persoalan atau fenomena sosial yang terjadi dimasyarakat dengan kajian dan deskripsi ilmiah dan guru mengupayakan untuk meluruskan konsep dan ide-ide siswa sehingga ditemukan suatu jawaban yang tepat, bijak, dan sesuai.

\section{METODE PENELITIAN}

Metode yang digunakan classroom action research. Classroom action research merupakan penelitian yang melibatkan unsur-unsur pendidikan (guru, kepala sekolah, siswa, orangtua siswa, pemangku kepentingan) secara penuh dalam rangkaian proses pembelajaran. Kemis and Taggart (dalam Kusumah, 2010) bahwa classroom action research yaitu hakekatnya berupa perangkat-perangkat atau Langkah-langkah dengan setiap siklus terdiri atas empat tahapan, yiatu: planning, acting, observing, reflekting. jika siklus pertama belum mendapatkan hasil yang maksimal maka penelitian berlanjut ke siklus kedua dengan tahapan seperti siklus satu, begitu seterusnya hingga tujuan dari penelitian tercapai. Tahap Planing peneliti serta guru mengadakan kolaborasi dalam menyusun rencana pembelajaran model Predict, Observe, and Explain. Tahap acting guru melakukan pembelajaran dengan model Predict, Observe, and Explain sesuai dengan yang direncanakan tahap observasi peneliti pengamatan terhadap proses pembelajaran baik terhadap hasil belajar dan aktifitas siswa proses pembelajaran setiap siklus menganalisa kekurangan dan kelemahan sebagai bahan replaning siklus berikutnya.

\section{HASIL DAN PEMBAHASAN}

\section{A. Siklus I}

Pada siklus I, pembelajaran muatan IPS tentang tema 1: indahnya kebersamaan subtema keragaman budaya bangasaku melalui Model Predict, Observe, and Explain.

Tabel 1:

Presentase hasil belajar pembelajaran IPS melalui model Predict, Observe, and Explain.

\begin{tabular}{|c|l|c|}
\hline No. & \multicolumn{1}{|c|}{ Jenis Data } & Siklus I \\
\hline 1 & $\begin{array}{l}\text { Presentase hasil belajar pembelajaran muatan IPS } \\
\text { dengan Model Predict, Observe, and Explain }\end{array}$ & $52 \%$ \\
\hline 2 & Presentasi pemantuan tindakan guru & $70 \%$ \\
\hline 3 & Presentasi pemantuan tindakan siswa & $60 \%$ \\
\hline 4 & $\begin{array}{l}\text { Rata-rata presentase hasil belajar pembelajaran } \\
\text { muatan IPS dengan Model Predict, Observe, and } \\
\text { Explain pada pertemuan 1 sampai pertemuan 5. }\end{array}$ \\
\hline 5 & $\begin{array}{l}\text { Rata-rata pemantuan tindakan guru pada } \\
\text { pertemuan 1 sampai pertemuan 5 }\end{array}$ & $70 \%$ \\
\hline 6 & $\begin{array}{l}\text { Rata-rata pemantuan tindakan siswa pada } \\
\text { pertemuan 1 sampai pertemuan 5 }\end{array}$ & $60 \%$ \\
\hline
\end{tabular}

Berdasarkan perolehan data Siklus I pada tabel 1 diatas bahwa pembelajaran muatan IPS melalui model Predict, Observe, and Explain belum memenuhi standar Ketuntasn Kriteria Minimal yaitu $80 \%$ sehingga perlu untuk dilanjutkan ke Siklus II dengan 5 pertemuan. Siswa yang memperoleh nilai di atas KKM (> 80) sebanyak 13 siswa yaitu $52 \%$ dari 25 . Berdasarkan pengamatan guru dan siswa masih terdapat kelemahan-kelemahan. Guru terlihat masih kaku dalam melakukan model Predict, Observe, and Explain ini, sehingga guru belum melakukan sepenuhnya langkah-langkah model Predict, Observe, and Explain ini. Siswa masih memerlukan adaptasi dengan model Predict, Observe, and Explain ini. Terlihat beberapa siswa kebingungan melakukan aktifitas sesuai perintah guru. Sehingga berdasarkan hasil pengamatan siklus ini perlu melakukan perbaikan-perbaikan pada siklus berikutnya. Secara visual hasil model Predict, Observe, and Explain pada siklus 1 terlihat pada grafik 1 dibawah ini: 


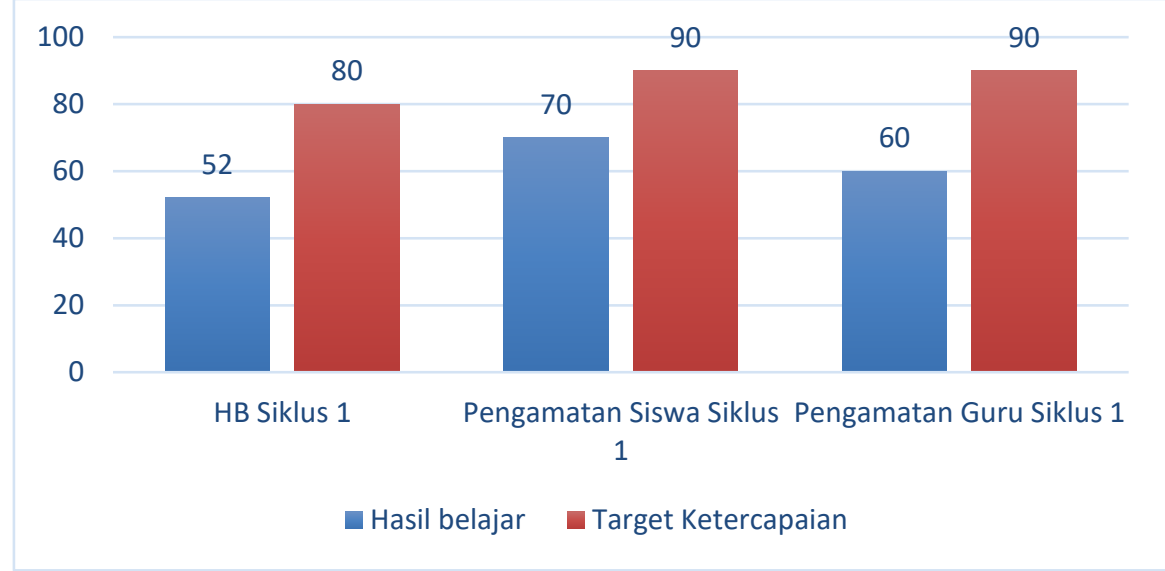

Grafik 1: Hasil belajar Muatan IPS dan Hasil Pengamatan siswa dan guru pada Siklus 1

\section{B. Siklus II}

Pada siklus II, pembelajaran muatan IPS tentang tema 1: indahnya kebersamaan subtema keragaman budaya bangasaku melalui Model Predict, Observe, and Explain.

Tabel 2:

Presentase hasil belajar pembelajaran IPS melalui model Predict, Observe, and Explain.

\begin{tabular}{|c|l|c|}
\hline No. & \multicolumn{1}{|c|}{ Jenis Data } & Siklus II \\
\hline 1 & $\begin{array}{l}\text { Presentase hasil belajar pembelajaran muatan IPS } \\
\text { dengan Model Predict, Observe, and Explain }\end{array}$ & $65 \%$ \\
\hline 2 & Presentasi pemantuan tindakan guru & $78 \%$ \\
\hline 3 & Presentasi pemantuan tindakan siswa & $74 \%$ \\
\hline 4 & $\begin{array}{l}\text { Rata-rata presentase hasil belajar pembelajaran } \\
\text { muatan IPS dengan Model Predict, Observe, and } \\
\text { Explain pada pertemuan 1 sampai pertemuan 5. }\end{array}$ & $78 \%$ \\
\hline 5 & $\begin{array}{l}\text { Rata-rata pemantuan tindakan guru pada } \\
\text { pertemuan 1 dan pertemuan 5 }\end{array}$ & $74 \%$ \\
\hline 6 & $\begin{array}{l}\text { Rata-rata pemantuan tindakan siswa pada } \\
\text { pertemuan 1 sampai pertemuan 5 }\end{array}$ & 78 \\
\hline
\end{tabular}

Berdasarkan perolehan data Siklus II pada tabel 2 diatas bahwa pembelajaran muatan IPS melalui model Predict, Observe, and Explain belum memenuhi standar Ketuntasan Kriteria Minimal yaitu $80 \%$ sehingga perlu untuk dilanjutkan ke Siklus II dengan 5 pertemuan. Pengamatan pada siklus II baik terhadap siswa maupun guru terlihat sudah menunjukan ada peningkatan pada hasil belajar IPS maupun penguasaan guru terhadap model Predict, Observe, and Explain, tapi belum memenuhi sesuai target dari penelitian. siswa terlihat mulai adaptasi dengan model Predict, Observe, and Explain ini tapi masih perlu dibimbing bagaimana melakukan prediksi, observsai maupun langkah menjelaskan dalam muatan IPS ini. Guru sudah terlihat luwes dalam melakukan pembelajaran model ini, tapi belum sepenuhnya mengusai model ini dalam mengimplementasikan pada muatan IPS. Pembelajaran pada siklus II belum sesuai apa yang ditargetkan oleh peneliti baik hasil belajar siswa maupun pengusaan guru terhadap model Predict, Observe, and Explain ini sehingga masih perlu dilajutkan kepada siklus III. Sebagai gambaran pembelajaran pada siklus II ini nampak pada grafik 2 di bawah ini: 


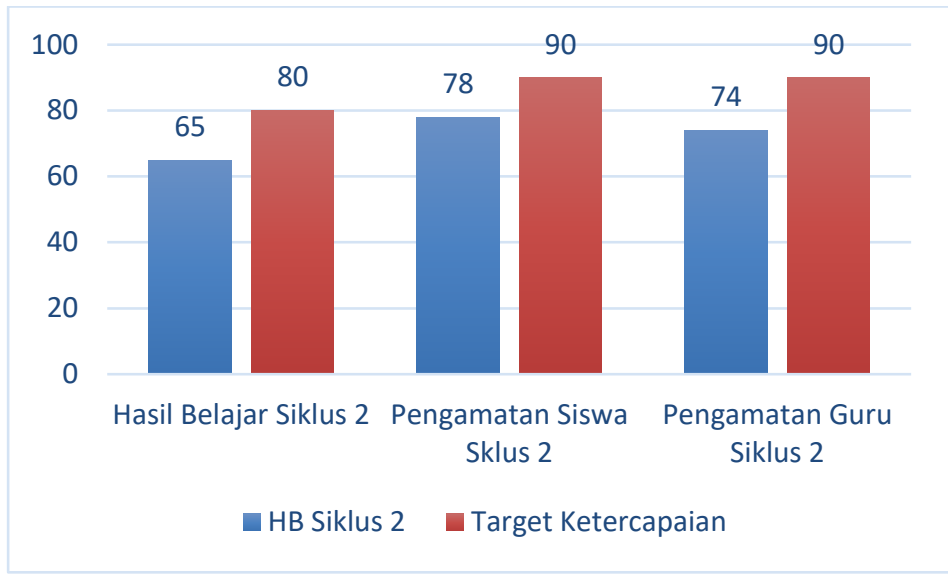

Grafik 2: Hasil belajar Muatan IPS dan Hasil Pengamatan siswa dan guru Siklus 2

\section{Siklus III}

Pada siklus III, pembelajaran muatan IPS tentang tema 1: indahnya kebersamaan subtema keragaman budaya bangasaku melalui Model Predict, Observe, and Explain.

Tabel 3:

Presentase hasil belajar pembelajaran IPS melalui model Predict, Observe, and Explain.

\begin{tabular}{|c|l|c|}
\hline No. & \multicolumn{1}{|c|}{ Jenis Data } & Siklus III \\
\hline 1 & $\begin{array}{l}\text { Presentase hasil belajar pembelajaran muatan IPS } \\
\text { dengan Model Predict, Observe, and Explain }\end{array}$ & $100 \%$ \\
\hline 2 & Presentasi pemantuan tindakan guru & $96 \%$ \\
\hline 3 & Presentasi pemantuan tindakan siswa & $92 \%$ \\
\hline 4 & $\begin{array}{l}\text { Rata-rata presentase hasil belajar pembelajaran } \\
\text { muatan IPS dengan Model Predict, Observe, and } \\
\text { Explain pada pertemuan 1 sampai pertemuan 5. }\end{array}$ \\
\hline 5 & $\begin{array}{l}\text { Rata-rata pemantuan tindakan guru pada } \\
\text { pertemuan 1 sampai pertemuan 5 }\end{array}$ & $96 \%$ \\
\hline 6 & $\begin{array}{l}\text { Rata-rata pemantuan tindakan siswa pada } \\
\text { pertemuan 1 sampai pertemuan 5 }\end{array}$ & $92 \%$ \\
\hline
\end{tabular}

Berdasarkan perolehan data Siklus III pada tabel 3 diatas bahwa pembelajaran muatan IPS melalui model Predict, Observe, and Explain sudah memenuhi standar Ketuntasan Kriteria Minimal yaitu hasil belajarn IPS diatas $80 \%$ dan hasil tindakan yang dilakukan oleh guru lebih dari 90\%. Pada siklus ke III ini baik hasil belajar siswa maupun kemampuan guru dalam melaksanakan model Predict, Observe, and Explain sudah mencapai target dari penelitian ini, dengan demikian pengunaan model Predict, Observe, and Explain dirasakan lebih bermakna dan berhasil menambah prestasi belajar dikelas. Secara visual hasil model Predict, Observe, and Explain pada siklus ke III terlihat pada grafik di bawah ini:

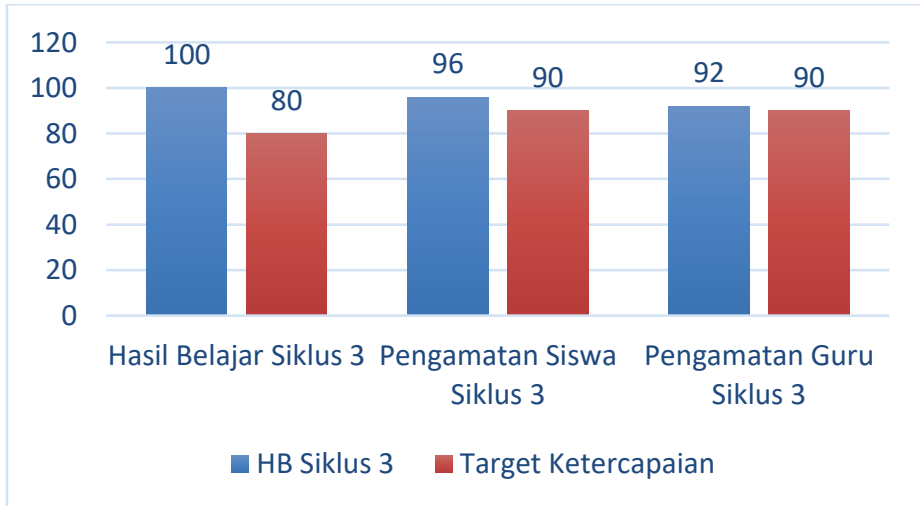

Grafik 3: Hasil belajar Muatan IPS dan Hasil Pengamatan siswa dan guru Siklus 3 


\section{KESIMPULAN}

Model Predict, Observe, and Explain menekankan siswa untuk dapat membuat prediksi atas suatu masalah atau peristiwa, lalu observasi dalam bentuk mendiskusikan masalah tersebut dengan langkah ilmiah, serta membuat simpulan atau solusi kemudian mereka mereka menyampaikan masalah tersebut untuk diberikan tanggapan yang komrehensif. Model Predict, Observe, and Explain diupayakan berdampak positif bagi siswa bagi prestasi belajar siswa pada muatan IPS di Sekolah dasar.

Penggunaan model Predict, Observe, and Explain dapat memberikan makna baik bagi siswa karena pelajaran yang sulit dimengerti dan dipahami oleh siswa akan dengan mudah dipahami, siswa secara bertahap dan kontinyu belajar untuk memahami tema indahnya kebersamaan subtema keragaman budaya bangasaku dalam muatan IPS dengan belajar dan memberikan solusinya.

\section{DAFTAR PUSTAKA}

[1] Daldjoeni. 1981. Dasar-dasar IPS. Bandung: Alumni

[2] Isjoni. (2007). Integrated learning, pendekatan pembelajaran IPS di pendidikan dasar. Pekanbaru: Falah Production.

[3] Kusumah, Wijaya dan Dedi Dwitagama, 2010, Mengenal Penelitian Tindakan Kelas (Jakarta: Indeks).

[4] Sumaatmadja, Nursid. (1986). Perspektif Studi Sosial. Bandung: Penerbit Alumni

[5] Suyono \& Hariyanto. 2015. Implementasi Belajar \& Pembelajaran. Bandung: Remaja Rosdakarya

[6] S. Teerasong, et.al. (2007). Development of a Predict-Observe-Explain Strategi for Teaching Flow Injektion an Undegraduate Chemistry, in the Internasioal Journal of Learning, Vol. 17, No. 3, 2007, hal. 137. 